\title{
Environmental Factors Affecting the Severity of Alternaria Brown Spot of Citrus and Their Potential Use in Timing Fungicide Applications
}

\author{
L. W. Timmer, Professor, H. M. Darhower and S. E. Zitko, Senior Biologists, T. L. Peever, Assistant in Plant \\ Pathology, and A. M. Ibáñez and P. M. Bushong, Senior Biologists, University of Florida, Citrus Research and \\ Education Center, 700 Experiment Station Road, Lake Alfred 33850
}

\begin{abstract}
Timmer, L. W., Darhower, H. M., Zitko, S. E., Peever, T. L., Ibáñez, A. M., and Bushong, P. M. 2000. Environmental factors affecting the severity of Alternaria brown spot of citrus and their potential use in timing fungicide applications. Plant Dis. 84:638-643.

Alternaria brown spot affects many tangerines and their hybrids, causing lesions on leaves, twigs, and fruit resulting in reduced yield and fruit quality. Field studies were conducted in a severely affected Minneola tangelo grove in central Florida from 1996 to 1998 to determine the environmental factors associated with infection of field trees and potted trap plants. Conidial production peaked following large flushes of new leaves, which were heavily infected. Most infections occurred during the summer rainy season, but trap plants became infected nearly every week of the year. When plants were exposed for 1-week periods, linear regression analysis indicated that disease severity on trap plants was positively related to the amount of rainfall, duration of leaf wetness, and average daily temperatures, and negatively related to the number of conidia trapped. Similar relationships occurred with trap plants exposed for 24-h periods on 141 different dates, except that temperature was not a significant factor. Nevertheless, these factors individually or combined in stepwise multiple regressions explained only a low percentage of the variability in disease severity with both weekly and daily trap plant sampling. When daily environmental data were categorized as: (i) rain versus no rain, (ii) $<10 \mathrm{~h}$ or $>10 \mathrm{~h}$ leaf wetness duration, and (iii) average temperature $<20^{\circ} \mathrm{C}, 20$ to $28^{\circ} \mathrm{C}$, and $>28^{\circ} \mathrm{C}$, relationships to disease severity on trap plants were clearer. Disease severity on days with rain was nearly double that of days without rain, but considerable infection occurred on days with $>10 \mathrm{~h}$ leaf wetness duration and no rain. Infection was greatest on days with temperatures of 20 to $28^{\circ} \mathrm{C}$ and slightly less at lower or higher temperatures. A point system, called the ALTER-RATER, was designed whereby each day would be assigned a severity value according to the prevailing environmental conditions. A fungicide application would be made after a predetermined number of points had accumulated. Simulated spray programs based on accumulation of 50,75, 100, and 150 points from historical weather data at several locations indicated that from 8 to 15,6 to 8,5 to 6 , or 3 to 4 sprays, respectively, would be needed depending on year and location in Florida. Such a weather-based control system could reduce the number of fungicide applications and improve control of Alternaria brown spot of tangerine.
\end{abstract}

Alternaria brown spot is a serious disease of tangerines (Citrus reticulata) and their hybrids in Florida and most humid and semiarid growing regions (21). The causal agent was originally described as Alternaria citri Ellis \& N. Pierce (14) and later renamed A. alternata (Fr.:Fr.) Keissl. pv. citri (18). Simmons (17) recently described 10 new species from our worldwide collection of Alternaria isolates from

Corresponding author: L. W. Timmer

E-mail: 1wt@1al.ufl.edu

Current address of S. E. Zitko: American Cyanamid Co., Princeton, NJ 08543-0400. Current address of T. L. Peever: Department of Plant Pathology, Washington State University, Pullman 99164.

Florida Agricultural Experiment Station Journal Series R-07206.

Accepted for publication 28 February 2000.

Publication no. D-2000-0331-02R

(c) 2000 The American Phytopathological Society citrus, including two species from tangelo (C. reticulata $\times$ C. paradisi) in Florida. We will refer to the pathogen herein as Alternaria sp., since proper classification of the pathogen remains in doubt.

Alternaria brown spot was first identified in central Florida on Dancy tangerines in 1974 (26). The disease now occurs statewide in most groves of susceptible cultivars. Florida has about 20,000 ha of tangerines and tangerine hybrids, about two-thirds of which are planted to susceptible cultivars such as Minneola and Orlando tangelo, Murcott tangor, Dancy tangerine, and most hybrids of Dancy such as Sunburst, Nova, and Lee (5).

Alternaria brown spot attacks young leaves, twigs, and fruit, causing small black necrotic spots after a 24- to 36-h incubation period. The pathogen produces a host-specific toxin (9) that causes lesions to expand, often resulting in leaf and fruit drop and twig dieback. On more mature fruit, lesions may vary from small necrotic spots to large, sunken pockmarks. Thus, this disease may affect tree growth, cause considerable crop loss, and produce blemishes on fresh fruit that are unacceptable to the consumer. All tangerines and their hybrids in Florida are produced for the fresh market, and fruit for processing has little value (5).

Leaves are susceptible to infection from the time of formation until they are fully expanded and hardened, and fruit are susceptible from petal fall until they reach about $5 \mathrm{~cm}$ in diameter, which is usually mid- to late July in Florida. Cultural measures such as wider tree spacing, the elimination of overhead irrigation, and avoidance of excess nitrogen fertilizer and water has helped reduce disease severity in some groves $(21,23,27)$. However, fungicide applications are essential for disease control and production of blemish-free fruit.

Our overall goal is to develop a weatherbased system to aid in timing of fungicide applications to improve disease control and to reduce the number of fungicide applications needed. Considerable research has been conducted on Alternaria diseases of potato and tomato, and a number of predictive models, such as EPIDEM, FAST, and some newer models, have been developed $(6,11,15,25)$ to aid in timing sprays. Predictive models are also available for Alternaria on apples (4) and carrots (8), and for Stemphylium vesicarium, a closely related pathogen, on pears (12). These systems involve either annual crops or temperate, deciduous fruits where epidemics develop within the course of a year. With citrus, Alternaria brown spot becomes endemic in the grove, and the period during the year when the disease is inactive is relatively short. Thus, models developed for other crops provide little assistance in developing programs for citrus.

In our earlier work, we found that release of conidia of Alternaria sp. on citrus was triggered by rainfall events and by sudden changes in relative humidity (24). In our laboratory studies, the optimum temperature for infection was 23 to $27^{\circ} \mathrm{C}$ (2). In Israel, Solel and Kimchi (19) reported that the optimum was 22 to $25^{\circ} \mathrm{C}$. In Florida, the minimum leaf wetness period required for infection was about $8 \mathrm{~h}$ at optimum temperature, but $12 \mathrm{~h}$ was required for important levels of infection (2). In our previous field work (24), we were unable to relate environmental variables to infection of potted trap plants on a weekly basis. 
In this study, we attempted to relate infection by Alternaria sp. on citrus on a weekly and daily basis to environmental factors and conidial numbers, and to develop a system for timing of fungicide application based on weather.

\section{MATERIALS AND METHODS}

Weekly sampling. Studies were conducted in a 10-year-old Minneola tangelo grove near Polk City, FL, that was severely affected by Alternaria brown spot. The amount of susceptible tissue present and disease severity were monitored weekly on trees in the grove. A total of 21 trees, seven trees in each of three rows separated by two nontest trees, were used for sampling. On each test tree, three branches, initially about $1.5 \mathrm{~m}$ long, were marked. Each week, the number of immature shoots present was counted on each branch to monitor the amount of susceptible tissue. Twenty susceptible leaves on each branch, selected arbitrarily, were examined for the presence of symptoms and the proportion of infected leaves calculated for each marked branch.

Seedlings of Dancy tangerine (C. reticulata), which are highly susceptible to brown spot, were placed in the grove at weekly intervals as trap plants to determine the amount of infection weekly. Eight greenhouse-grown seedlings in 2.5-liter pots with susceptible new shoots were placed in the grove in the same area as the marked trees. Trap plants were returned to the greenhouse and evaluated after 2 to 5 days under dry conditions. Sets of trap plants were placed in the grove each week from April 1996 to February 1998. Initially, only the proportion of diseased shoots in relation to total shoots was recorded each week. After September 1996, the number of lesions per leaf on all susceptible leaves was counted and averaged for all susceptible leaves.

Airborne conidia were trapped continuously from April 1996 to February 1998 in the grove. A 7-day volumetric spore trap similar to that described by Gadoury and MacHardy (7), as modified in our previous study (24), was used for the first year. In the second year, a Burkard volumetric spore sampler (Burkard Scientific Sales, Ltd., Rickmansworth, Hertfordshire, UK) was used. The spore trap tapes were coated with a base layer consisting of gelvitol (35 $\mathrm{g})$, glycerol $(50 \mathrm{ml})$, phenol $(2 \mathrm{~g})$, and distilled water $(100 \mathrm{ml})$, followed by a second adhesive coating consisting of petroleum gel (25 g), paraffin wax (12 g), and toluene $(50 \mathrm{ml})$. Less toluene was used in summer when temperatures were high. The 7-day tapes were removed from the drum, cut into 1-day segments, mounted on microscope slides, and stained with cotton bluelactophenol. The number of conidia was counted in a single pass along the length of the tape at $\times 160$ magnification and recorded as the total number of Alternaria conidia observed per week. Previous studies (24) in this grove indicated that nearly all the Alternaria conidia are pathogenic on Minneola tangelo.

Temperature, leaf wetness, and rainfall were monitored with a Campbell $21 \mathrm{X}$ micrologger (Campbell Scientific, Inc., Logan, UT) for the first year. In the second year, the Adcon AgroExpert System (Adcon Telemetry, Los Angeles, CA) was used to monitor environmental variables. Environmental monitors were located within the row at the site of a missing tree. Data were collected at about $2 \mathrm{~m}$ above the soil surface. Leaf wetness sensors were placed with a northerly exposure and fixed at a 30-degree angle from the horizontal. Data were collected every $15 \mathrm{~min}$.

Daily sampling. In addition to the weekly trap plants, four Dancy tangerines with susceptible shoots were placed in the field for 24-h periods from noon on one day until noon the next day on 141 different dates from June 1997 to October 1998. Plants were returned to the greenhouse and incubated for 2 to 5 days under dry conditions. The number of lesions per leaf was counted, and the average number for each day was calculated. The number of conidia per day was monitored using the Burkard volumetric spore sampler, and environmental factors were measured using the Adcon system.

Data analyses. Disease severity was estimated as the number of lesions per leaf on trap plants and related to environmental factors because data for disease severity on field trees were not available for many weeks due to lack of susceptible tissue. Disease severity was related to the amount of rainfall, the average temperature, the number of hours of leaf wetness, and the number of conidia on a weekly or daily basis using regression analyses. Linear and stepwise multiple regression analyses were conducted using the GLM procedure in SAS (SAS Institute, Inc., Cary, NC). Square root and logarithmic transformations of the data were also investigated.

In a separate analysis, disease severity data from the daily trap plant studies were divided into various categories. These categories were established based on our previous laboratory and field studies $(2,24)$ and the results of the regression analyses described above. The categories chosen were rainfall $(<2.5 \mathrm{~mm},>2.5 \mathrm{~mm})$, leaf wetness $(<10 \mathrm{~h},>10 \mathrm{~h})$, and temperature $\left(<20^{\circ} \mathrm{C}, 20\right.$ to $28^{\circ} \mathrm{C}$, and $\left.>28^{\circ} \mathrm{C}\right)$.

Based on the disease severity that resulted from the different sets of conditions and previous studies, we assigned a point value for each day for Alternaria brown spot severity. This is similar to some predictive systems, such as FAST $(11,15)$, which base fungicide applications on the number of points accumulated depending on weather conditions. Using this system, we simulated the number of sprays that would be needed and the spray intervals assuming various trigger scores and using different environmental conditions. We selected point score totals of 50, 75, 100, and 150 for comparison, which were values that resulted in feasible spray intervals. We obtained weather data from the Adcon AgroExpert system obtained from Terra, Inc. (now Agro Distribution, Sioux City, IA) from Polk City and Lake Alfred in central Florida in 1997, 1998, and 1999, as well as from Ft. Pierce on the east coast and Immokalee in southwest Florida in 1999. We assumed that the first spray would be applied in all programs on 15 March to protect the spring flush of growth. Thereafter, all applications would be based on the point score accumulated. It was assumed that no sprays would be applied after 15 July, by which time fruit becomes resistant in Florida.

\section{RESULTS}

Weekly sampling. Weekly estimates of the amount of new growth, disease severity on new growth on field trees and trap plants, conidia captured, and environmental factors revealed the seasonal pattern of disease development in each year (Fig. 1). In 1996 to 1997, there was a strong growth flush in late April to May that became heavily infected following some rain and extended periods of dew. A large peak in conidial production occurred in late May to early June following the period of severe infection of abundant new growth. Disease intensity on branches and trap plants diminished in late July and early August during a period of low rainfall and minimal leaf wetness. Infection was high again in September and early October despite low numbers of conidia and few susceptible shoots on grove trees. Some infection occurred during winter when dew periods were prolonged despite low temperatures.

In 1997 to 1998, the spring flush of growth that occurred late February to March largely escaped infection, probably due to the lack of rain (Fig. 1). Unlike in 1996, there was no large peak in conidia. Rainfall was high in the summer, and the trap plants and new flush on grove trees became severely affected. High rainfall extended into the fall and winter, and disease levels on trap plants continued to be high. Despite relatively high disease severity, the number of conidia remained at low to moderate levels.

Despite some apparent correspondence between various weather factors and infection in the field trees and on trap plants, the relationships as determined by regression analysis were weak (Table 1). Disease severity on trap plants was significantly related to the number of hours of leaf wetness, average weekly temperature, and the amount of rainfall (Table 1). However, the relationship with the number of conidia captured was negative, but also significant. Even when all weather factors were com- 

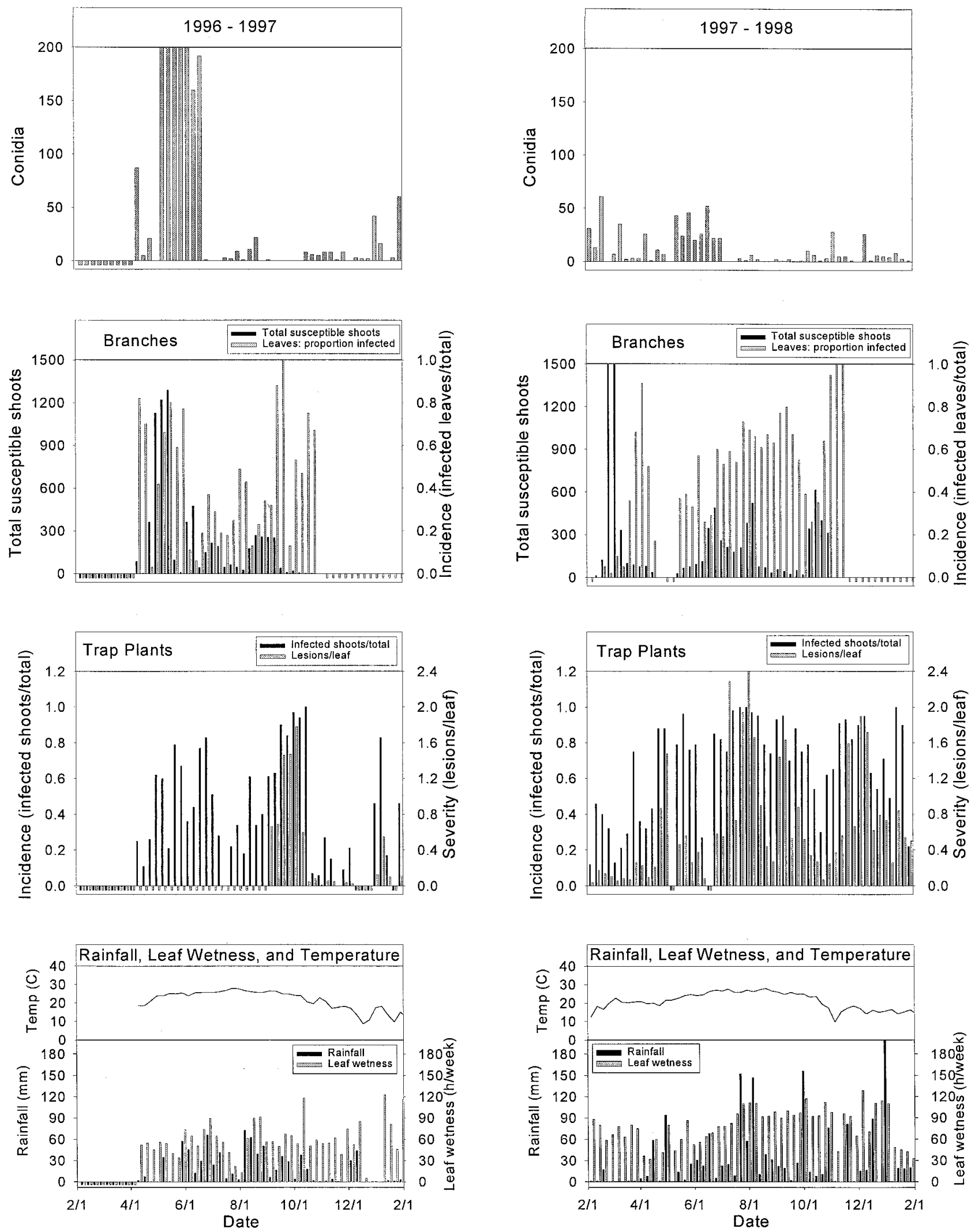

Fig. 1. Number of conidia captured, number and disease incidence on new shoots of field trees, disease incidence, and severity on potted Dancy tangerine trap plants, and environmental conditions in a Minneola tangelo grove near Polk City, FL, in 1996-97 and 1997-98. Values for total numbers of conidia that exceed maximum on graph in 1996-97 were 358, 323, 269, 647, and 1,061 in chronological order. Values for total numbers of susceptible shoots that exceed maximum on graph in 1997-98 were 4,395 and 3,818, in that order. The value for lesions per leaf on trap plants in 1997-98 that exceeds the maximum is 2.5 lesions per leaf. The value for rainfall that exceeds the maximum in 1997-98 is $430 \mathrm{~mm}$. Negative values on all graphs indicate missing data. 
bined in a stepwise multiple regression analysis, they still only accounted for about $22 \%$ of the variability. Various transformations of data did not greatly increase the amount of variability explained (data not shown). Examination of data plots did not suggest that curvilinear relationships would be more appropriate.

Daily sampling. Similar linear regression analyses of the data collected during 24-h periods on 141 dates were even less effective in explaining the variability in the disease severity on trap plants (Table 2). Disease severity was significantly related to the hours of leaf wetness and rainfall amount, but not to temperature. Severity was again negatively related to the number of conidia captured. The combination of leaf wetness and rainfall in stepwise multiple regression analysis only explained about $7 \%$ of the variability.

Categorization of the data from trap plants exposed for 24-h periods was more informative. Despite a rather weak relationship between severity and rainfall amount, the number of lesions per leaf was much greater on days with rain than on days without rain, especially when temperatures were favorable for infection (Table 3). When daily leaf wetness periods were short and no rain fell, disease severity was low even at optimum temperatures. Even without rain, disease severity was moderate on days when leaf wetness periods exceeded $10 \mathrm{~h}$. Average daily temperatures below $20^{\circ} \mathrm{C}$ or above $28^{\circ} \mathrm{C}$ reduced the number of lesions per leaf somewhat, but relatively few days with those conditions were encountered. During the entire test, we did not encounter a single day with rain where leaf wetness duration was less than $10 \mathrm{~h}$.

Development of a predictive system. Based on the disease severity occurring on trap plants exposed for 24-h periods, points were assigned (Table 3 ). Where no data were available for a given set of environmental conditions, the number of points assigned was based on laboratory studies published previously (2). Adjustments were made in the number of points assigned where disease severity values were based on very few data points.

Potentially, fungicide applications could be made following the accumulation of a certain number of disease severity points assigned to each date based on the environmental conditions on that day. The arbitrarily selected values of 50,75, 100, and 150 accumulated points were used to simulate the number of sprays that would be predicted based on environmental factors in several locations and years (Table 4). The minimum and maximum number of days between sprays that would be required were also determined (Table 4). Using an accumulated score of 50, up to 15 applications would have been predicted for the Immokalee and Ft. Pierce locations in 1999. If the severity score of 150 was needed to trigger an application, then only three applications would be predicted in Lake Alfred in 1999. The interval between applications could be as short as 5 days or as long as 55 , depending on the severity score selected and the location and year (Table 4).

\section{DISCUSSION}

Alternaria brown spot severity on trap plants using weekly sampling was positively, but weakly, related to the amount of rainfall, duration of leaf wetness, and temperature. These relationships were not unexpected given previous field results (24) and a nonlinear response to temperature in laboratory tests (2). One of the reasons for lack of a stronger relationship to leaf wetness with weekly sampling is that we were measuring multiple infection periods during a week of trap plant exposure. The effect of prolonged and interrupted wetting periods on infection of citrus is unknown.

We speculated that relationships might be stronger if we measured the amount of infection on a daily rather than a weekly basis. However, infection was still only weakly related to leaf wetness and rainfall, and not related to temperature, although measurements were made on 141 individual dates.

Numbers of conidia captured were negatively related to the amount of infection in both weekly and daily sampling. Initially, this seemed incongruous since rain events trigger release of conidia of Alternaria sp. on citrus (24). However, since rains also wash conidia from the air $(10,25)$ and increase infection, this relationship may not be so surprising. In this study, high conidia counts followed, rather than preceded, major infection periods.

Even though quantitative relationships of Alternaria disease severity with environmental factors were weak, categorization of data, based on laboratory studies (2), was revealing. The greater severity of brown spot on days with rain may have been partially due to the extended wetting periods on days with rain and to deposition of conidia on leaves by rain drops. Infection occurred even in the absence of rain if leaf wetness durations were greater than 10 $\mathrm{h}$, which explains the importance of the disease in semiarid areas such as Israel and Turkey $(1,18)$, where no rain falls after flowering and infection is strictly dependent on dew. Temperature appeared to have a lesser effect, but in Florida, there are relatively few days during the major period of concern from March to July with average temperatures outside of the 20 to $28^{\circ} \mathrm{C}$ range. Those days, as observed in this study, tend to be cold and dry following cold fronts in spring or hot and dry during occasional periods in summer.

Since infection occurs very rapidly and symptoms may appear in $24 \mathrm{~h}$ with Alternaria brown spot, it is impossible to predict disease and apply fungicides before infection occurs. However, extended periods of

Table 1. Regression analyses of the effect of weekly average temperature, total hours of leaf wetness, rainfall amount, and total number of conidia on number of lesions per leaf on Dancy tangerine

\begin{tabular}{lcccc}
\hline $\begin{array}{l}\text { Linear regression } \\
\text { Factor }\end{array}$ & Slope & $\boldsymbol{R}^{\mathbf{2}}$ & $\boldsymbol{P}$ & $\mathbf{n}$ \\
\hline Leaf wetness $(\mathrm{h})$ & +0.0082 & 0.132 & 0.0019 & 78 \\
Temperature $\left({ }^{\circ} \mathrm{C}\right)$ & +0.0451 & 0.115 & 0.0038 & 78 \\
Rainfall $(\mathrm{mm})$ & +0.0026 & 0.065 & 0.0323 & 78 \\
Conidia & -0.0115 & 0.071 & 0.0246 & 78 \\
Stepwise multiple regression & & & & $\mathbf{n}$ \\
Factor & Partial $\boldsymbol{R}^{2}$ & Model $\boldsymbol{R}^{2}$ & 0.0019 & 78 \\
Leaf wetness & 0.132 & 0.132 & 0.0232 & 78 \\
Temperature & 0.064 & 0.195 & 0.1395 & 78 \\
Rainfall & 0.026 & 0.221 & & \\
\hline
\end{tabular}

a Trap plants were exposed to infection by Alternaria sp. for 1-week periods in a Minneola tangelo grove from September 1996 to February 1998.

Table 2. Regression analyses of the effect of average daily temperature, total hours of leaf wetness, rainfall amount, and total number of conidia on disease severity and number of lesions per leaf on Dancy tangerine

\begin{tabular}{lccc}
\hline $\begin{array}{l}\text { Linear regression } \\
\text { Factor }\end{array}$ & Slope & $\boldsymbol{R}^{\mathbf{2}}$ & $\boldsymbol{P}$ \\
\hline Leaf wetness $(\mathrm{h})$ & +0.0036 & 0.055 & 0.0052 \\
Temperature $\left({ }^{\circ} \mathrm{C}\right)$ & -0.0010 & 0.002 & 0.6023 \\
Rainfall (mm) & +0.0019 & 0.046 & 0.0103 \\
Conidia & -0.0024 & 0.033 & 0.0327 \\
Stepwise multiple regression & & & $\boldsymbol{P}$ \\
Factor & Partial $\boldsymbol{R}^{2}$ & Model $\boldsymbol{R}^{2}$ & 0.0066 \\
Leaf wetness & 0.053 & 0.053 & 0.0792 \\
Rainfall & 0.021 & 0.074 & \\
\hline
\end{tabular}

a Trap plants were exposed to infection by Alternaria sp. for 24-h periods on 141 dates during 1997 and 1998. 
leaf wetness promote conidia production on old leaf lesions, and rainfall triggers release of spores (24). Thus, periodic applications based on weather can reduce inoculum buildup on leaves as well as protect fruit for a period of time. We propose to assign point values to the conditions occurring each day and to use an accumulated point score to trigger fungicide application as is done in FAST and other models $(11,15)$. The points were assigned primarily on the basis of the amount of infection on trap plants in daily sampling. However, days with certain sets of conditions were never or rarely encountered in our field study. In those cases, points were assigned or adjusted based on previous laboratory studies (2). The point score system will be designated as the ALTER-RATER.

In Florida, copper fungicides, ferbam, and neem oil are the only products registered for control of brown spot (22). Applications are often made on a 10- or 14-day schedule, and even then control is often not satisfactory. In Colombia, weekly sprays are needed (3), and even in semiarid areas such as Israel and South Africa, six to eight applications per year may be necessary $(16,18,20)$.

When we simulated using ALTERRATER point values of 50 to 150 to trigger fungicide applications in different years and locations, we found the number of sprays could vary from 3 to 15 . In a few cases, the predicted number of sprays even exceeded the number that would be used in a 10-day program. This exercise illustrates several important points. The number of applications in high areas with good air circulation and cooler temperatures, such as Lake Alfred in central Florida, is slightly lower than in areas with poor air circulation such as Polk City. Many more sprays would be needed in warmer and wetter locations on the east coast and in southwest Florida (Ft. Pierce and Immokalee). We now recommend that Alternaria-susceptible cultivars be planted primarily in central Florida where air circulation is better and wetting periods shorter (23). It is also apparent that standard programs based on routine applications are not likely to result in the most effective control. During rainy periods, spray intervals may need to be as short as 5 to 10 days, but intervals can probably be extended up to more than 30 days during relatively dry weather. Use of the ALTERRATER may not always reduce the number of sprays needed, but should improve the overall level of control achieved.

The most appropriate accumulated point score for use in triggering fungicide applications will need to be determined by further experimentation. However, it is likely that no one point score will serve in all cases. Cultivars such as Minneola tangelo and Dancy tangerine are highly susceptible, but Nova and Orlando tangelo, Murcott tangors, and some other hybrids are less susceptible (13). Also, disease history will have to be taken into consideration since some locations have been heavily infested for many years, whereas others have a less severe problem. We suggest that a trigger score of 50 would be appropriate for a heavily infested Minneola grove, whereas a score of 150 might be more appropriate for a lightly infested Murcott or Nova planting. This system has been designed in and is probably most applicable to Florida conditions. However, many of the principles involved may be useful in controlling Alternaria brown spot in other growing areas.

\section{ACKNOWLEDGMENTS}

This research was supported in part by the Florida Citrus Production Research Advisory Council, Project 961-4. We appreciate the technical assistance of Turksen Kamber and Jennifer Parsons and thank T. R. Gottwald for helpful discussions.

\section{LITERATURE CITED}

1. Canihos, Y., Erkilic, A., and Timmer, L. W. 1997. First report of Alternaria brown spot of Minneola tangelo in Turkey. Plant Dis. 81:1214.

2. Canihos, Y., Peever, T. L., and Timmer, L. W. 1999. Temperature, leaf wetness, and isolate effects on infection of Minneola tangelo leaves by Alternaria sp. Plant Dis. 83:429433.

3. Castro-Caicedo, B. L., and Montoya-Restrepo, E. C. 1996. Control químico de la mancha foliar del tangelo Minneola. Alternaria tenuissima. Avances Técnicos 234. Cenicafe, Chinchiná, Caldas, Colombia.

4. Filajdic, N., and Sutton, T. B. 1992. Influence

Table 4. The number of fungicide applications predicted for four locations in 1997 to 1999 using different accumulated point scores to trigger fungicide sprays with a weather-based model for Alternaria brown spot

\begin{tabular}{lccccc}
\hline \multirow{2}{*}{$\begin{array}{l}\text { Accumulated } \\
\text { point score }\end{array}$} & Year & \multicolumn{3}{c}{ No. of applications (min. and max. spray intervals) } \\
\cline { 2 - 6 } & Lake Alfred & Polk City & Ft. Pierce & Immokalee \\
\hline 50 & 1997 & $11(7-15)^{\mathrm{a}}$ & $11(9-17)$ & $\ldots$ & $\ldots$ \\
& 1998 & $8(12-30)$ & $10(7-21)$ & $\ldots$ & $\ldots$ \\
75 & 1999 & $9(11-22)$ & $10(8-26)$ & $15(5-12)$ & $15(5-14)$ \\
& 1997 & $7(11-23)$ & $8(13-24)$ & $\ldots$ & $\ldots$ \\
100 & 1998 & $6(17-37)$ & $7(13-30)$ & $\ldots$ & $\ldots$ \\
& 1999 & $6(11-30)$ & $7(11-33)$ & $10(8-18)$ & $10(9-20)$ \\
150 & 1997 & $6(15-28)$ & $6(18-29)$ & $\ldots$ & $\ldots$ \\
& 1998 & $5(19-45)$ & $5(22-38)$ & $\ldots$ & $\ldots$ \\
10-day program & 1999 & $5(17-40)$ & $5(15-43)$ & $8(14-23)$ & $8(12-24)$ \\
14-day program & 1997 & $4(31-43)$ & $4(26-44)$ & $\ldots$ & $\ldots$ \\
21-day program & 1998 & $3(46-56)$ & $4(35-46)$ & $\ldots$ & $\ldots$ \\
\hline
\end{tabular}

${ }^{a}$ Minimum and maximum spray intervals in days in parentheses.

b No data.

Table 3. The number of lesions of Alternaria brown spot per leaf observed on Dancy tangerine trap plants exposed for $24 \mathrm{~h}$ under different categories of environmental conditions in a Minneola tangelo grove near Polk City, FL, on 141 dates during 1997-98

\begin{tabular}{|c|c|c|c|c|c|c|c|c|}
\hline $\begin{array}{l}\text { Rain } \\
(\mathbf{m m})\end{array}$ & $\begin{array}{l}\text { Leaf wetness } \\
\text { (h) }\end{array}$ & $\begin{array}{c}\text { Temperature } \\
\left({ }^{\circ} \mathbf{C}\right)\end{array}$ & $\begin{array}{c}\text { No. of } \\
\text { observations }\end{array}$ & $\begin{array}{c}\text { Temp }\left({ }^{\circ} \mathbf{C}\right) \\
\pm \text { SE }\end{array}$ & $\begin{array}{l}\mathbf{L W}(\mathbf{h}) \\
\pm \mathrm{SE}\end{array}$ & $\begin{array}{l}\text { Rain (mm) } \\
\pm \mathrm{SE}\end{array}$ & $\begin{array}{l}\text { Lesions/leaf } \\
\quad \pm S E\end{array}$ & $\begin{array}{l}\text { Disease } \\
\text { score }\end{array}$ \\
\hline$>2.5$ & $>10$ & $<20$ & 4 & $17.9 \pm 1.0$ & $17.2 \pm 2.1$ & $24.0 \pm 11.2$ & $0.05 \pm 0.04$ & $(6)^{\mathrm{a}}$ \\
\hline$>2.5$ & $>10$ & $20-28$ & 35 & $25.2 \pm 0.3$ & $17.0 \pm 0.5$ & $16.1 \pm 2.3$ & $0.11 \pm 0.02$ & 11 \\
\hline$>2.5$ & $>10$ & $>28$ & 0 & ${ }^{\mathrm{b}}$ & .. & $\ldots$ & $\ldots$ & (8) \\
\hline$>2.5$ & $<10$ & $<20$ & 0 & $\ldots$ & $\ldots$ & $\ldots$ & $\ldots$ & (3) \\
\hline$>2.5$ & $<10$ & $20-28$ & 0 & $\ldots$ & $\ldots$ & $\ldots$ & $\ldots$ & (6) \\
\hline$>2.5$ & $<10$ & $>28$ & 0 & $\ldots$ & $\ldots$ & $\ldots$ & $\ldots$ & (4) \\
\hline$<2.5$ & $>10$ & $<20$ & 14 & $15.5 \pm 0.9$ & $13.5 \pm 0.5$ & $0.04 \pm 0.04$ & $0.06 \pm 0.02$ & 6 \\
\hline$<2.5$ & $>10$ & $20-28$ & 44 & $25.0 \pm 0.3$ & $13.4 \pm 0.3$ & $0.25 \pm 0.09$ & $0.06 \pm 0.01$ & 6 \\
\hline$<2.5$ & $>10$ & $>28$ & 5 & $28.5 \pm 0.4$ & $12.0 \pm 0.6$ & $0.20 \pm 0.20$ & $0.04 \pm 0.03$ & 4 \\
\hline$<2.5$ & $<10$ & $<20$ & 3 & $11.5 \pm 2.6$ & $5.4 \pm 2.0$ & 0.00 & $0.07 \pm 0.03$ & (0) \\
\hline$<2.5$ & $<10$ & $20-28$ & 29 & $26.2 \pm 0.3$ & $2.3 \pm 0.6$ & $0.05 \pm 0.04$ & $0.03 \pm 0.01$ & 3 \\
\hline$<2.5$ & $<10$ & $>28$ & 7 & $29.0 \pm 0.2$ & $4.2 \pm 1.6$ & 0.00 & 0.00 & 0 \\
\hline
\end{tabular}

a Points in parentheses assigned based primarily on laboratory leaf wetness duration-temperature studies (2).

${ }^{\mathrm{b}}$ No data. 
of temperature and wetness duration on infection of apple leaves and virulence of different isolates of Alternaria mali. Phytopathology 82:1279-1283.

5. Florida Agricultural Statistics Service. 1998. Citrus Summary, 1996-97. U.S. Dep. Agric., Agric. Mark. Serv. Natl. Agric. Statistics Serv., Orlando, FL.

6. Franc, G. D., Harrison, M. D., and Lahman, L. K. 1988. A simple day-degree model for initiating chemical control of potato early blight in Colorado. Plant Dis. 72:851-854.

7. Gadoury, D. M., and MacHardy, W. E. 1983. A 7-day recording volumetric spore trap. Phytopathology 73:1526-1531.

8. Gillespie, T. J., and Sutton, J. C. 1979. A predictive scheme for timing fungicide applications to control Alternaria leaf blight in carrots. Can. J. Plant Pathol. 1:95-99.

9. Kohmoto, K., Scheffer, R. P., and Whiteside, J. O. 1979. Host selective toxins from Alternaria citri. Phytopathology 69:667-671.

10. Langenberg, W. J., Sutton, J. C., and Gillespie, T. J. 1977. Relation of weather variables and production of airborne spores of Alternaria dauci. Phytopathology 67:879-883.

11. Madden, L., Pennypacker, S. P., and MacNab, A. A. 1978. FAST, a forecast system for $A l$ ternaria solani on tomato. Phytopathology 68:1354-1358

12. Montesinos, E., Moragrega, C., Llorente, I., Vilardell, P., Bonaterra, A., Ponti, I., Bugiani, R., Cavanni, P., and Brunelli, A. 1995. Development and evaluation of an infection model for Stemphylium vesicarium on pear based on temperature and wetness duration. Phytopathology 85:586-592.

13. Peever, T. L., Olsen, L., Ibáñez, A., and Timmer, L. W. 2000. Genetic differentiation and host specificity among populations of Alternaria spp. causing brown spot of grapefruit, and tangerine $\times$ grapefruit hybrids in Florida. Phytopathology 90:407-414.

14. Pegg, K. G. 1966. Studies of a strain of Alternaria citri Pierce, the causal organism of brown spot of Emperor mandarin. Queensl. J. Agric. Anim. Sci. 23:14-18.

15. Rotem, J. 1994. The Genus Alternaria. Biology, Epidemiology, and Pathogenicity. American Phytopathological Society, St. Paul, MN.

16. Schutte, G. C., Lesar, K. H., Pelser, P. du T., and Swart, S. H. 1992. The use of tebuconazole for the control of Alternaria alternata on 'Minneola' tangelos and its potential to control post-harvest decay when applied as a preharvest spray. Proc. Int. Soc. Citric. 7:10701074.

17. Simmons, E. G. 1999. Alternaria themes and variations (226-235): Classification of citrus pathogens. Mycotaxon 70:263-323.

18. Solel, Z. 1991. Alternaria brown spot on Minneola tangelo in Israel. Plant Pathol. 40:145-147.

19. Solel, Z., and Kimchi, M. 1998. Histopathology of infection of Minneola tangelo by Alternaria alternata pv. citri and the effect of host and environmental factors on lesion development. J. Phytopathol. 145:389391.
20. Solel, Z., Oren, Y., and Kimchi, M. 1997. Control of Alternaria brown spot of Minneola tangelo with fungicides. Crop Prot. 16:659664.

21. Timmer, L. W. 1998. Diseases of fruit and foliage. Pages 107-115 in: Citrus Health Management. L. W. Timmer and L. W. Duncan, eds. American Phytopathological Society, St. Paul, MN.

22. Timmer, L. W. 1999. Alternaria brown spot. Pages 221-222 in: Florida Citrus Pest Management Guide. J. L. Knapp, ed. Univ. Fla. Coop. Ext. Serv. Publ. SP-43.

23. Timmer, L. W., and Peever, T. L. 1997. Managing Alternaria brown spot. Citrus Ind 78(6):24-25.

24. Timmer, L. W., Solel, Z., Gottwald, T. R., Ibáñez, A. M., and Zitko, S. E. 1998. Environmental factors affecting production, release, and field populations of conidia of $A l-$ ternaria alternata, the cause of brown spot of citrus. Phytopathology 88:1218-1223.

25. Waggoner, P. E., and Horsfall, J. A. 1969 EPIDEM: A simulator of plant disease written for a computer. Conn. Agric. Exp. Stn. Bull. 698, New Haven, CT

26. Whiteside, J. O. 1976. A newly recorded Alternaria-induced brown spot disease on Dancy tangerines in Florida. Plant Dis. Rep. 60:326-329.

27. Whiteside, J. O. 1988. Alternaria brown spot of mandarin. Page 8 in: Compendium of Citrus Diseases. J. O. Whiteside, S. M. Garnsey, and L. W. Timmer, eds. American Phytopathological Society, St. Paul, MN. 